\title{
What The CPA's Think About The Proposed Changes To Lease Accounting
}

Stuart Shough, University of South Carolina Upstate, USA

\begin{abstract}
The Financial Accounting Standards Board and the International Accounting Standards Board jointly issued a Discussion Paper soliciting comments on a proposed standard on leases. This paper presents the results from 417 CPA's responses to selected questions asked in the Discussion Paper.
\end{abstract}

Keywords: FASB proposed lease accounting

\section{INTRODUCTION}

\begin{abstract}
ease accounting has been criticized by users for many years. One of the criticisms of current accounting standards is that many leases are structured to avoid capitalization providing the lessee a source of unrecognized financing that can be difficult for users to understand. Many users think that operating leases also give rise to assets and liabilities that should be recognized in the financial statements. Another criticism stems from companies being able to account for a similar transaction in very different ways, capital versus operating, which impairs comparability for users. On 19 March 2009, the FASB and IASB issued a Discussion Paper entitled, Leases: Preliminary Views that deals only with accounting for lessees that addresses these and other concerns of constituents.
\end{abstract}

\section{CURRENT ACCOUNTING STANDARDS}

Current accounting standards require lessees to account for their leases as either capital leases or operating leases. Capital leases transfer to the lessee a significant amount of the risks and rewards of ownership of the leased asset, therefore requiring the lessee to recognize an asset and liability in their statement of financial position. Operating leases only transfer the right to use the property to the lessee and require the lessee to recognize lease expense as lease payments are made.

The Financial Accounting Standards Board has ruled that a lease should be treated as a capital lease if it meets any one of the following four conditions

- $\quad$ if there is a transfer of ownership to the lessee at the end of the lease term

- $\quad$ if there is an option to purchase the asset at a "bargain purchase price" at the end of the lease term

- $\quad$ if the lease term equals or exceeds $75 \%$ of the estimated economic life of the asset

- $\quad$ if the present value of the minimum lease payments equals or exceeds $90 \%$ of the fair market value of the asset

\section{PROPOSED NEW APPROACH}

The proposed new standard would require the lessee to recognize an asset representing its right to use the leased item for the lease term (measured initially at cost, which equals the present value of the lease payments) and to recognize a liability for its obligation to pay rentals (measured initially at the present value of the lease payments). 
The proposed new standard would eliminate operating leases. The subsequent measurement of both the obligation and the right-of-use asset would be an amortized cost-based approach.

\section{What Do The CPA's Think}

The boards tentatively decided to adopt an approach to lessee accounting that would require the lessee to recognize:

(a) an asset representing its right to use the lease item for the lease term

(b) a liability for its obligation to pay rental

Do you support the proposed approach?

$\begin{array}{lll}\text { Yes } & \text { No } & 44 \% \\ \end{array}$

\section{NON-CORE ASSET LEASES}

Some constituents have proposed to only capitalize assets that are essential to the operations (core assets). They maintain that leases for non-core assets are of little interest to the users and the costs to recognize and measure the assets and liabilities outweigh the benefits, for example, the assets and liabilities for leasing an automobile to a taxi company is useful information to the users of the financial statements, but not if the lessee is a computer repair chain. Theses constituents think that non-core asset leases should be accounted for as operating leases.

\begin{tabular}{|c|c|c|c|}
\hline \multirow{2}{*}{\multicolumn{4}{|c|}{$\begin{array}{l}\text { What Do The CPA's Think } \\
\text { Should the proposed new standard exclude non-core asset leases? }\end{array}$}} \\
\hline & & & \\
\hline Yes & $42 \%$ & No & $58 \%$ \\
\hline
\end{tabular}

\section{SHORT-TERM LEASES}

Some constituents have also stated that short-term leases should be excluded from the proposed standard and continued to be accounted for as operating leases.

In their opinion, the costs of recognizing and measuring the rights and obligations arising under short-term lease contracts outweigh the benefits.

\section{What Do The CPA's Think}

Should the proposed new standard exclude short-term leases?

Yes No No $\quad$ No $28 \%$

\section{ACCOUNTING FOR MORE COMPLEX LEASES} include:

Lease contracts can extend a range of rights and obligations to the lessee for example, a lease contract may

- $\quad$ Options to extend the lease

- $\quad$ Options to terminate the lease early

- $\quad$ Options to purchase the leased asset

- $\quad$ Obligations to pay variable rentals or contingent rentals

- $\quad$ Obligations to make up for the value of the leased asset below a specified value (residual value guarantees) 
The proposed standard could require the lessee to recognize and measure each of the rights and obligations separately (a components approach) but the boards decided that the lessee should recognize:

- $\quad$ A single right-of-use asset that includes rights acquired under options

- A single obligation to pay rentals that includes obligations arising under contingent rental arrangements and residual value guarantees

\section{What Do The CPA's Think}

The boards tentatively decided not to adopt a components approach to lease contracts. Instead, the boards tentatively decided to adopt an approach whereby the lessee recognizes:

(a) a single right-of-use asset that includes rights acquired under options

(b) a single obligation to pay rentals that include obligations arising under contingent rental agreements and residual value guarantees

Do you support this proposed approach?

\begin{tabular}{lll} 
Yes & No $\quad 42 \%$ \\
\hline
\end{tabular}

\section{MEASURING THE OBLIGATION TO PAY RENTALS}

The boards discussed whether to require the lessee to measure the obligation to pay rentals initially at fair value, but decided to use the present value of the obligation for the initial measurement.

Which discount rate to use had to be determined.

- The lessors discount rate would cause the present value of the obligation to be equal with the fair value of the asset

- The lessee's incremental borrowing rate if higher than the lessor's discount rate would cause the present value of the obligation to be less than the fair value of the asset

Existing standards require lessees to use the lessor's discount rate if it is practicable to determine that rate and if it is not practicable to determine that rate, the lessee's incremental borrowing rate is used.

The boards decided to initially measure the obligation using the lessee's incremental borrowing rate and noted that in most leases this would be a reasonable approximation to fair value of the obligation.

However, variations between company's incremental borrowing rates will cause differences in the amount of depreciation and interest expense recognized:

- $\quad$ a good credit rating and lower incremental borrowing rate will result in recording a larger asset and therefore higher depreciation and lower interest expense over the lease term

- a poor credit rating and higher incremental borrowing rate that will result in a lower asset and therefore lower depreciation and higher interest expense over the lease term

What Do The CPA's Think

Do you agree with the board's tentative decision to measure the lessee's obligation to pay rental at the present value of the lease payments discounted using the lessee's incremental borrowing rate?
Yes
$69 \%$
No
$31 \%$ 


\section{MEASURING THE RIGHT-OF-USE ASSET}

The boards decide to measure the right-of-use asset initially at cost rather than fair value and noted that:

- $\quad$ Cost equals the present value of the obligation discounted using the lessee's incremental borrowing rate

- In a lease contract, the cost of the right-of-use asset will generally equal the fair value of the obligation to pay rentals

\section{What Do The CPA's Think}

Do you agree with the board's tentative decision to measure the lessee's right-of-use asset at cost?

$$
\text { Yes }
$$

$76 \%$

No

$$
24 \%
$$

\section{SUBSEQUENT MEASUREMENT}

The boards tentatively decided to adopt an amortized cost-based approach to subsequent measurement of the obligation and the right-of-use asset instead of using fair value.

Under this approach the lease payments would be apportioned between interest expense and a reduction of the outstanding obligation. The asset would be amortized over the shorter of the lease term or useful life of the asset.

The boards also discussed whether to require the lessee to revise its obligation due to changes in the incremental borrowing rate but decided not to require remeasurement.

\section{What Do The CPA's Think}

The boards tentatively decided to adopt an amortized cost-based approach to subsequent measurement of both the obligation and the right-of-use asset?

Do you agree with this proposed approach?

$$
\text { Yes }
$$

$75 \%$

No

$25 \%$

\section{What Do The CPA's Think}

Should a new lease accounting standard permit a lessee to elect to measure it's obligation to pay rentals at fair value?

$$
\text { Yes }
$$

$29 \%$

No

$71 \%$

\section{What Do The CPA's Think}

Should the lessee be required to revise its obligation to pay rentals to reflect changes in its incremental borrowing rate?

$$
\text { Yes }
$$

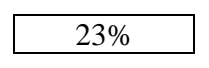

No

$$
77 \%
$$

\section{CONCLUSION}

The survey shows that the CPA's favor the proposed new approach but clearly do not think short-term leases should be included. The single right-of-use approach to measurement was favored by the CPA's which would indicate they preferred using a more practical method to determining the cost of the asset instead of a more involved 
components approach. The overwhelming majority do not favor fair value accounting for the obligation or accounting for changes in the lessee's incremental borrowing rate.

\section{AUTHOR INFORMATION}

Stuart Shough has worked in the private sector for 12 years and has taught accounting for 27 years. He is currently Senior Instructor at the George Dean Johnson, Jr. College of Business and Economics at the University of South Carolina Upstate.

\section{REFERENCES}

Available from author. 
NOTES 